\title{
An Examination of Dawud (David A.S) Fasting For Women and its Effectiveness from Physio-Psychological Perspective
}

\author{
Q A Sholikhah ${ }^{1}, \mathrm{H}_{\text {Aliyah }}^{2}$ \\ ${ }^{1}$ Islamic Building School of Jagad Alimussirry Surabaya, Indonesia \\ ${ }^{2}$ Science Department, Universitas Negeri Surabaya \\ Email: aininsholikhah@gmail.com
}

\begin{abstract}
This research was conducted to determine the urgency of Dawud fasting for women from a physio-psychological perspective. This research is a type of qualitative descriptive research, by making direct observations or observations. The target of this study is to determine the urgency of Dawud fasting in women from the perspective of physio-psychology and Sufism for students of the Jagad Alimussirry Islamic boarding school. The data collection technique was carried out by means of interview and literature review. Meanwhile, for data analysis, the researcher used an interactive model from Miles and Huberman and to test the validity of the data,the researcher used Triangulation technique. The results obtained that the habit of Dawud Sunnah fasting for women could make them accustomed to be able to introspect (muhasabah) their own mistakes, be patient and sincere, motivate oneself to think positively and optimistically, be empathetic towards others and adapt well to the environment. Dawud fasting is very important and suitable for the fair sex. By not leaving Lillahita'ala's intention to worship, it will automatically train a variety of things that can guide a women in facing every problems in their life as well as making a women special not only physically but also psychologically and spiritually.
\end{abstract}

Keywords: Dawud fasting, Women, Physical-psichology,

\section{INTRODUCTION}

In the view of Islam, women are noble creatures, who are given the law so that they are protected from all dangers. Women possessed extraordinary powers that the opposite sex had never better possessed namely the power of love, empathy and loyalty. With their love, they strengthen the steps of those with them, their empathy awakens those who fall and their loyalty is timeless, unbroken by change. Women are the source of life. They risked their life for a new life, and breasting flowed reviving milk. So that all their sacrifices deserved to place them in the glory of heaven, as well as the majesty of reverence.
Rasulullaah SAW. Said about the role of women in developing the welfare of life, both in the family and in society. The upright or the fall of a nation is determined by the women. If they are good then it will be saved and if they are not well, they will destroy the country. Rasulullah also said that heaven is under the soles of the mother's feet. It is also not an exaggeration if Rasulullah enacted a woman (Fatima) as the first person to accompany him in heaven.

Nurussakinah (2015) argued that women are no longer just talking about kitchens, mattresses and wells. More than that, women with their gender also already have a solid standing foundation so that their situation is not neglected, considering that their existence in 
the midst of life have provided various colors in enlightenment and change. Women with their gender are women who are able to position themselves not only as women from a biological perspective, but also from a psychological perspective, values, and role so that they will appear in behavior according to their gender.

Women in adolescence are a period when women are in a phase of transition, change, problematic age to a time when looking for selfidentity and so on. In adolescence, there is a rapid emotional rise which is influenced by hormones, as well as physical changes accompanied by sexual maturity. This causes a lot of demands and pressures on a teenager in this phase. Most teenagers are ambivalent in dealing with the changes that occur. On the one hand, they want freedom but on the other hand, they fear the responsibility that comes with that freedom. They doubt their own ability to assume the responsibility. (Putro, K, 2017)

After entering adolescence, women will continue their lives into the adult phase, when at adulthood women are associated with a marriage, which in this phase women also experience changes in life phases, especially in the psychological phase. Hart and Hart (Mokoginta, 2001) explain that problems in marriage already exist in the first year of marriage. These problems include problems related to finances, sister or brother in-laws, parent in laws, friends, conflict resolution and in the division of roles. Marriage is a process that needs a long and mature consideration for women. The role changing of a women themselves to be wife who are ready to take care of the household is a stage that really needs adjustment.

Women in every stages of life experience various changes both physically and psychologically. These changes can also indirectly affect women's spirituality. Spiritual intelligence is an intelligence or the ability to deal with problems related to the meaning and placing behavior in human life. It also interpreted as an assessment that certain actions in life are more meaningful than others (Agustian, 2005).

Fasting is a form of worship that can be a way for someone to be able to control all their behavior. From 'Abdullah bin' Amr bin Al 'Ash, he said that the Prophet sallallaahu' alaihi wa sallam told him

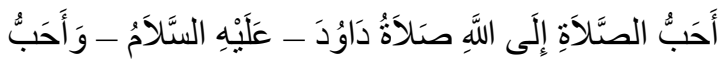

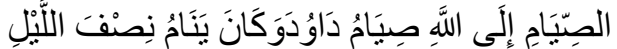

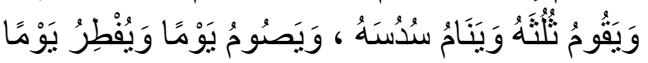

"The best prayer with Allah is the prayer of the Prophet Dawud 'alaihis salam. And the best of fasting with Allah is the fast of Dawud. Prophet Dawud used to sleep in the middle of the night and he prayed in the third of the night and slept again in the sixth. As for Dawud's fast, that is fasting one day and not fasting the next day. " (HR. Bukhari no. 1131).

The Dawud fast is a fast that was often performed by the Prophet Dawud (a.s) who did one day fasting no one day. As the Prophet said in the hadith above, Dawud fasting is a fast that is more important than any other sunnah fast. Dawud fasting can make the mental and thinking power of the perpetrator quickly change and adapt to various kinds of changes that occur, especially for women (Fathonah, 2011).

In his research, Fathonah (2011) also said that people who practice Dawud fasting will always be required to be people who always change, they are required to undergo obstacles and challenges that can thwart Daud's fast. These challenges come from ourselves or the environment that will always test the extent of mental resilience. As is always experienced by women at every stages of their physical and psychological development.

Women who are able to do the Dawud fasting will sincerely cause the nervous system to be calm, balanced and relaxed so that any imbalances in their physical or psychological 
development will be easy to control. Wijaya Kusuma (1997) stated that fasting can raise the degree of human feeling or emotional quotient (EQ) between being generous, willing to sacrifice, compassion and patience. Increased ability to control yourself when fasting is closely related to this EQ, resulting in increased patience and feelings of calm and freedom from feelings of anxiety.

When linked with changes in a women at all stages of their life, the Dawud fasting is perfect for helping women control their heart and mind to adjust and face life. As has been written, women will experience emotional ups and downs which cause a lot of demands and stresses. Not only that, Daud's fasting itself can also train discipline and self-control, such as being angry or hurting others. Doing daud fasting regularly and truly is expected to be able to control oneself from things that affect the low quality of emotional stability (Fathonah, 2011).

Research conducted by Amin Yusi Fathonah with the title "The Implementation of Dawud Fast and Its Relationship to Emotional Stability" states that Dawud fasting is proven to strengthen the soul, nourish the body, increase enjoyment and foster solidarity between people. Daud's fast has also been shown to be able to control one's emotions so that they will tend to be patient and control themselves. The results of the second study conducted by Muchammad Imron with the title "The Riyadlah Tradition of Fasting Daud in Memorizing the Koran at Al-Sholihah Jonggrangan Islamic Boarding School, Sumberadi Mlati Sleman Yogyakarta". he stated that with riyadlah fasting of Dawud can make them easier for students to memorize the Qur'an. , get closer to Allah, keep away from immorality or evil deeds, form a disciplined person, form a qur'ani soul and get great rewards and gifts from Allah.

Based on the research that has been done by other researcher, the writer took the initiative to conduct the same research entitled "An
Examination of Dawud (David A.S) Fasting for Women and its Effectiveness from PhysioPsychological Perspective"

\section{METHOD}

This type of research is a qualitative descriptive research, namely by making direct observations or observations, descriptive research is research that tries to describe a symptom, an event, an event that is happening at the moment. While qualitative research is a scientific research, which aims to understand a phenomenon in a natural social context by promoting a deep communication interaction process between the researcher and the phenomenon under study (Sugiyono, 2007).

The target of this study is to determine the urgency of Daud's fast in women from the perspective of physio-psychology and Sufism for students of the Jagad Alimussirry Islamic boarding school. To help obtain accurate data, a research instrument is needed in the form of a questionnaire containing a list of questions which is presented in a simple form so that the respondent can provide entries according to their wishes and circumstances. (Riduwan, 2013). The data collection technique was carried out by means of interviews and literature review.

The researcher used an interactive model from Miles and Huberman to analyze the research data. Activities in qualitative data analysis are carried out interactively and take place continuously until completion, so that the data is saturated (Riduwan, 2013). The interactive model is as follows:

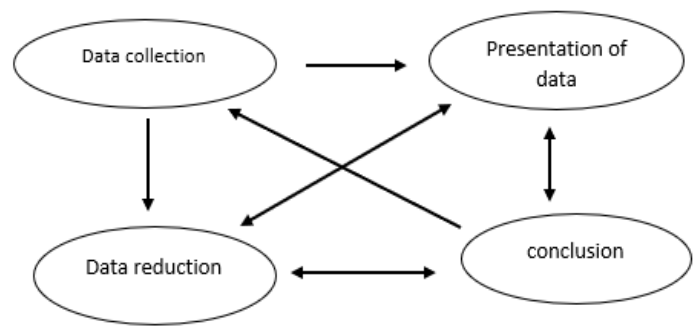

Figure 1. Components of Interactive Model Data Analysis 
To test the validity of the data, the examiner used the Triangulation technique. Denzin (Moleong, 2007) distinguishes four types of triangulation as a technique for checking the validity of data that utilizes the use of sources, methods, investigators and theories.

\section{RESULT AND DISCUSSION}

Based on the interview data obtained from the respondents, which is a case study of the Jagad Alimussirry Islamic boarding school students, the researcher gave several questions that were answered directly and openly by each respondent regarding the implementation of Daud's fast that he had done. Between the list of questions is divided into two important components. the first component is about David's fasting routine, while the second component is about the effect of Daud's fast on physio-psychology.

Based on in-depth interviews conducted by researchers with informants regarding how the existence of roses developed the spiritual motivation of the salik in the Jagad "Alimussirry Student Boarding School", similar results were obtained from one answer to another from each informant.

Among the questions to the respondent were what were the goals and motivations that made you fast Daud regularly, then HA answered as follows "Holding back my liridhoillah and my motivation is none other than to get closer to Allah".

Then the researcher further asked HA how much you want to fast in the sunnah of Daud, HA answered "I wish I could istoqomah dawud fasting. What is expected to be closer to Allah, heart and live peacefully for worship".

Then the researcher again asked HA what benefits and what big changes did you feel during the routine fasting of the sunnah of Daud?, HA answered "Rarely sick, thrifty, worship easier, all matters get smoother. changes that I experienced including improved health, decreased weight without complicated diets, digestive problems almost never. In terms of psychology I feel Life is calmer, so the happier. Thoughts are not easily complicated, they are ignorant of things that are not important, focus on wanting to get closer to Allah, emotions are more controlled, yes, fasting cannot be emotional, the feeling of the heart is getting softer.

Then still in the interview, the researcher asked HA, how long did you fast in the sunnah of Daud and do you feel heavy / burdened by doing it?, HA answered "From 2013 to 2016. Initially, it was hard, the more it was done, the more enjoyable it was".

The next question is: Are there any obstacles / problems that prevent you from fasting?, Does the busy daily activities of the students at the Islamic Boarding School prevent you from fasting in the sunnah of Daud? HA answered "Technically, there are no obstacles, socially, maybe I often don't hang out with friends during the day. Fasting is an invisible worship so keep your activities as usual "At the end of the interview, the researcher asked how important Daud's sunnah fast is in your opinion? HA answered "Daud's fast is important as a way of muhasabah, introspection, cleansing. Fasting is the most blessed service because often only we and God know. Sirr worship that only we and Allah can enjoy".

Furthermore, the informant interviewed by the researcher was ZM. ZM revealed that the purpose of Daud's fast was to follow the JA tirakat curriculum, and ZM's motivation to perform the Daud fast was because of the duty and responsibility, so that he ate a lot at that time ".

Then the researcher further asked ZM how much do you want to fast in the sunnah of Daud, ZM answered "Really want to because never, want to feel it". Then the researcher again asked $\mathrm{ZM}$ what benefits and big changes did you feel during the routine fasting of the sunnah of Daud?. ZM replied "The body feels easy to perform worship, increases patience, is given fluency. the changes that I experienced were 
nothing more than making me more patient, more aware of the difficult struggles of maintaining fasting. Psychologically, it becomes more mature.

Then still in the interview, the researcher asked ZM, how long did you fast in the sunnah of Daud and do you feel heavy / burdened by doing it?, ZM answered "3 months, it's hard at the beginning, but because of the intention, God willing, it's not a burden".

The next question is: Are there any obstacles / problems that prevent you from fasting? Does the busy daily activities of the students at the Islamic Boarding School prevent you from fasting in the sunnah of Daud?, ZM replie, "There are no serious obstacles, walk as usual, but be careful not to forget the days".

At the end of the interview, the researcher asked how important Daud's sunnah fast is in your opinion?, ZM replied "It is important because it can be a means to train our Islamic faith in worship".

Furthermore, the informant interviewed by the researcher was AM. AM revealed that the purpose and motivation of AM doing the fasting of Daud was. Besides carrying out his duties, God willing, it was always lillahita'ala, also because of his duties and responsibilities, so that he ate a lot less at that time ".

Then the researcher again asked AM what were the benefits and what big changes did you feel during the routine fasting of the sunnah of Daud?, AM replied "Be more willing to do a lot of good things, especially worship. Be more patient, because fasting daud also requires more consistency, because if you are not sure you can miss it. Psychologically, life is more calm, peaceful heart, easy to control emotions, more patient maybe in facing the difficulties of life.

Then still in the interview, the researcher asked AM, how long did you fast in the sunnah of Daud and do you feel heavy / burdened by doing it ?, AM replied "8 months, at first it might be tough because you are not used to it, but when you are used to it, it will be delicious."
The next question is: Are there any obstacles or problems that prevent you from fasting? Does the busy daily activities of the students at the Pesantren prevent you from fasting, the sunnah of Daud?, AM replied "There are no serious obstacles, proceed as usual".

At the end of the interview, the researcher asked how important Daud's sunnah fast is in your opinion?, AM replied "It is important, in addition to being able to train on istiqomahan, it also trains us to always be closer to Allah".

Furthermore, the last informant the researcher interviewed was NA. NA revealed that NA's purpose and motivation for fasting Daud was carrying out the duties of the teacher, expecting blessings from Aba kyai.

Then the researcher again asked NA what benefits and what big changes did you feel during the routine fasting of the Sunnah of Daud?, NA answered "You can control and control your emotions more, your body feels lighter, saves pocket money, of course. At first it seemed like I lost weight but after a while things returned to normal. Psychologically, I am more able to accept the existing situation sincerely, struggle hard against all challenges (which now unconsciously and sometimes I just realize it may be applied in my daily life now) more positive thinking so that the mind calms down and the body becomes healthier. Because I have heard information that thoughts also affect health, that's why people who are sick should not be asked to think heavily".

Then still in the interview, the researcher asked NA, how long did you fast in the sunnah of Daud and do you feel heavy / burdened by doing it?, NA answered "I have been running for almost a year. Maintaining joy is very hard, but because it is accompanied by a sense of love, what is not, all will be overcome too".

The next question is: Are there any obstacles / problems that prevent you from fasting? Does the busy daily activities of the santri at the Pesantren prevent you from fasting in the sunnah of Daud?, NA replied "There may be 
obstacles, but they are not too severe, such as being invited to eat together with friends often".

At the end of the interview, the researcher asked how important Daud's sunnah fast is in your opinion?, NA replied "As important as we set an alarm when we want to go to sleep to wake up, we make it a point to take care of ourselves even though we have asked a friend to wake up, when a friend forgets."

Specifically, the effect of Daud's fast on the physio-psychology experienced by each respondent based on the results of the interview is presented in the following table:

Table I. Effects of the Daud Fast on physiopsychology

\begin{tabular}{|l|l|l|l|l|}
\hline Component & HA & ZM & AM & NA \\
\hline $\begin{array}{l}\text { physical changes } \\
\text { (weight loss) }\end{array}$ & yes & yes & yes & yes \\
\hline Physical strength & yes & yes & yes & yes \\
\hline Cause pain & no & no & no & yes \\
\hline Emotion control & yes & yes & yes & yes \\
\hline $\begin{array}{l}\text { Differences in } \\
\text { character after fasting }\end{array}$ & yes & yes & yes & yes \\
\hline More optimistic & yes & yes & yes & yes \\
\hline More spirited & yes & yes & yes & yes \\
\hline Positive thinking & yes & yes & yes & yes \\
\hline To be better & yes & yes & yes & yes \\
\hline Diligent worship & yes & yes & yes & yes \\
\hline Disipline & yes & yes & yes & yes \\
\hline $\begin{array}{l}\text { Sensitive to } \\
\text { surroundings }\end{array}$ & yes & yes & yes & yes \\
\hline Appreciate & yes & yes & yes & yes \\
\hline Helpful & yes & yes & yes & yes \\
\hline
\end{tabular}

Based on research conducted by Rian Afghan (2018), it is stated that the habit of Daud's sunnah fasting among students can make them accustomed to being able to introspect (muhasabah) their own mistakes. Ability to refuse and sincere, able to motivate oneself to think positively and optimistically, able to prove empathy for others and able to adapt well to the environment. In addition, someone who is accustomed to running it will remain in good health.
In research conducted by Rian Afghan (2018), it is stated that another wisdom contained in fasting is so that people who are fasting can feel the blessings of Allah that have been bestowed on them. Because the abundance of favors makes one insensitive to the value of a gift given. Unable to appreciate it unless it is lost, with which Allah's blessings are felt special.

Daud's fast is a special fast as it is said in a hadith regarding the position of this Sunnah fast, which reads: "From Abdullah bin Amru he said: Rasulullah sallallaahu 'alaihi wasallam said: The most affectionate fast is that of my brother Daud, he fasts one day and one day. breaking the fast. " HR. Muslim (Bukhori, alJami 'al-Sahih Juz 2).

In his research, Fathonah (2011) said that people who practice Daud's fast will always be required to always change, they are required to undergo obstacles and challenges that can thwart Daud's fast. The features of Daud's fast that have been proven by the respondents themselves, that a woman who actually in their life experiences various changes both physically and psychologically from adolescence to adulthood is able to overcome all obstacles and challenges in her life. As expressed by respondents, physical and psychological changes greatly affect a woman's life.

Wijaya Kusuma (1997) states that fasting can raise the degree of human feeling or emotional quotient (EQ) between being generous, willing to sacrifice, compassion and patience. Increased ability to control yourself when fasting is closely related to this EQ, resulting in increased patience and feelings of calm and freedom from feelings of anxiety. Based on the results of interviews with respondents. A woman or woman who has a character that tends to be more sensitive than a man sometimes makes her anxious, stressed or even frustrated with something. Based on the results of interviews with several questions posed by researchers to respondents, the fast of 
Daud can foster a sense of enthusiasm, optimism, legowo, always think positively to be trustworthy and keep promises. Based on the experience of another researcher, he concluded that someone who fasts dawud will have a spirit of never giving up or being enthusiastic, not easily discouraged, brave and not afraid to be different. (Suyadi, 2007).

Based on interviews with respondents, it was stated that after they fasted Daud, they were always given peace of mind, felt close to Allah SWT, were sure and were confident about His love and grace given to all His creatures, this calm originated from the strong and solid foundation of Tauhid, that everything comes from Allah SWT, he is the creator of everything that happens, nothing else. The soul is described as a soul that always returns all problems to Allah SWT, is willing to all decisions of Allah SWT., Gathers with the Islamic ummah, and always longs for Allah SWT's paradise. (Ma'mur, 2009)

Changes in the character that occurred in the respondent explained that Daud's fast was able to make one's soul calmer. The soul is defined as the union or combination of the spirit and the body when humans are still in the womb. The spirit is holy as Allah wants it to be, while the body or body is impure. The soul is a combination of two entities, namely the purity of the spirit and the impurity of the body. Thus, the soul can be holy or impure, or a combination of the holy and impure (Afghan R, 2018).

\section{CONCLUSION}

Based on the formulation of the problem posed and the discussion above, this research can be rejected as follows:

1. The Daud's fast provides immense positive benefits to a woman who is able to live it, both physically and psychologically. In addition, the Daud's fast is a means of worship and taqarrub to Allah SWT.

2. The custom of fasting Sunnah Daud for women can make them accustomed to being able to introspect (muhasabah) their own mistakes. able to be patient and sincere, able to motivate oneself to think positively and optimistically, able to be empathetic towards others and able to adapt well to the environment. The essence of Daud's fast which is full of challenges requires patience, persistence, and perseverance to Allah SWT can train someone to haveistiqomah, determined when he wants to achieve something

3. Daud's fast is very important and suitable for the fair sex. by not leaving Lillahita'ala's intention to worship, it will automatically train a variety of things that can guide a woman in facing every problem in her life as well as make a woman special not only physically but also psychologically and spiritually.

\section{REFERENCES}

Abu 'Abdillah Muhammad bin Ismail alBukhari, 1403 H. Al-Jami' al-Sahih min Haditsi Rasulillah shallallahu 'alaihi wassalam wa Sunanihi wa Ayyamihi. Juz 2. Kairo: alMathba'ah as-Salafiyah wa Maktabuha. Cet. I.

Afghan R. 2018. Pembiasaan Puasa Sunnah Dawud Di Kalangan Santri Dan Hikmah-Hikmahnya Terhadap Kecerdasan Emosional Di Pesantren Tahfizh Daarul Qur'an Tangerang. Jakarta. UIN Syarif Hidayatullah Press. Agustian. Ary Ginanjar. 2005. Rahasia Sukses Membangun Kecerdasan Emosi dan Spiritual (ESQ) Berdasarkan 6 Rukun Iman dan 5 Rukun Islam. Jakarta: Arga.

Bey Arifin, dkk. Terjemah Sunan Nasa'iy jilid II. Searang: CV. Asy-Syifa'. Hadits no 2305.

Fathona Amin. 2011. Skripsi. Pelaksanaan Puasa Daud dan Hubungannya dengan kestabilan Emosi.

Ma'mur, Jamal Asmani, 2009. Kedasyatan Puasa Dawud. Jogyakarta: Mitra Pustaka.

Miles, B. Mathew dan Michael Huberman. 2014. Analisis data Kualitatif Buku Sumber Tentang Metode-Metode Baru. Jakarta : UIP. 
Nurhayati, E. 2012. Psikologi perempuan dalam berbagai perspektif. Yogyakarta : pustaka pelajar.

N Daulay. 2015. Pandangan Islam dan Psikologi terhadap Transformasi Perempuan. Al Tahrir, Vol 15.No 2 November 2015. STAIN Ponorogo.

KZ Putro. 2018. Memahami ciri dan tugas perkembangan masa remaja. Jurnal Aplikasi Ilmu-Ilmu Agama 17 (1), 2532.

Riduwan, M.B.A. Metode dan Teknik Menyusun Tesis (Bandung: Alfabeta 2013) Sugiyono. 2007. Metode Penelitian Pendidikan Pendekatan Kuantitatif, Kualitatif, dan $R \& D$. Bandung: Alfabeta.

Suyadi, 2012. Keampuhan Puasa Dawud, Yogyakarta: Pustaka Pelajar Offset.

Syarifuddin, Amir. 2014. Ushul Fiqh, Jilid 1. Jakarta: Kencana Prenadamedia Group. Wijayakusuma, M. Hembing. 1997. Puasa Itu Sehat. Jakarta : Gramedia Pustaka Utama. 